flats and the other in houses. It was found that the morbidity of those families who lived in flats was $57 \%$ greater than of those who lived in houses, and that the greatest differences were seen in the incidence of respiratory infections in young women and children, and of psychoneurotic disorders in women.

The reasons for the differences in respiratory infections were felt to be the relatively small space available in a flat compared with that in a house, and confinement of the family within the flat. This confinement, and the resulting social isolation, were thought to be the reasons for the increase in psychoneuroses in the women.

The families concerned had had a double social disturbance in that their family ties had been severed and they were also subject to the restricting environment of life in a flat, and it is suggested that in view of the large number of flats which are being built, and the tendency towards family mobility, further investigation is needed into the effects of flat life on health.

I am grateful to the Director-General of Medical Services, Royal Air Force, for permission to publish this paper.

REFERENCES

Brotherston, J. H. F., and Chave, S. P. W. (1956). Brit. F. prev. soc. Med., 10, 200.

Hird, J. F. B. (1966). F. Coll. gen. Practit., 12, Suppl. No. 1, p. 33.

Martin, F. M., Brotherston, J. H. F., and Chave, S. P. W. (1957). Brit f. prev. soc. Med., 11, 196.

Registrar General (1954). Medical and Population Subjects Study, No. 8 "Measurement of Morbidity." Report of the Statistics Subcommittee of the Registrar General's Advisory Committee on Medical mittee of the Registrar Generatics. H.M.S.O., London.

Taylor, S. J. L., and Chave, S. P. W. (1964). Mental Health and Environment. London.

Young, M., and Willmott, P. (1962). Family and KInship in East London, 2nd ed. London.

\title{
Effect of Gastrin II on Gastric Emptying and Secretion During a Test Meal
}

\author{
J. N. HUNT,* M.D., D.SC., M.R.C.P. ; N. RAMSBOTTOM,* M.B., B.S.
}

Brit. med. Y., 1967, 4, 386-390

Hypersecretion of gastrin by an islet cell tumour of the pancreas is believed to be the cause of the Zollinger-Ellison syndrome (Zollinger and Ellison, 1955; Gregory, Tracy, French, and Sircus, 1960). Patients with this condition have extreme gastric hypersecretion and peptic ulceration. In one case described by Lawrie, Williamson, and Hunt (1962) there was also very rapid gastric emptying. This feature seemed to be explained when Smith and Hogg (1966) found that injected gastrin stimulated gastric motility as judged by measurements of intraluminal pressure. We therefore expected that an increase in the rate of gastric emptying would result from intravenous infusion of gastrin, but this was not so.

\section{Procedure}

The plan of the experiments is set out in Fig. 1. Three test meals were given in succession with a 10 -minute interval between them. For the 10 minutes before and during the second meal a continuous intravenous infusion of gastrin was given. The stomach was washed out with $250 \mathrm{ml}$. of water before each meal in order to remove any residual secretion. Each of the three tests of gastric emptying, which lasted 10 minutes, was separated from the subsequent test by 10 minutes. The meals consisted of $750 \mathrm{ml}$. of $100 \mathrm{mN}$ sodium citrate containing $30 \mathrm{ml}$. of a saturated solution of phenol red per litre as marker. They were instilled down a tube into the stomach in about 75 seconds. This meal was chosen because it empties very rapidly; also it is buffered by the presence of the citrate ion, so minimizing the possible slowing action of secreted acid. Immediately after recovery of the first meal injection of gastrin into the running intravenous infusion was begun and continued for 20 minutes. Hog gastrin II was used in doses ranging from 0.125 to $3 \mu \mathrm{g} . / \mathrm{min}$.

The recovered gastric contents were analysed according to the method of Hunt (1954, 1959). The volumes of original meal present in the recoveries were calculated as the product of the volume recovered and the ratio of its phenol red con- centration to that of the original meal. The parietal secretion was calculated and expressed as millilitres of $160 \mathrm{mN} \mathrm{HCl}$. The two of us, $75-\mathrm{kg}$. men aged 50 and 27 , were the subjects for this investigation.

\section{Results}

The meal which was given during the infusion of gastrin left the stomach more slowly than the preceding or the succeeding meal. The minimal effective dose of gastrin in subject N. R.

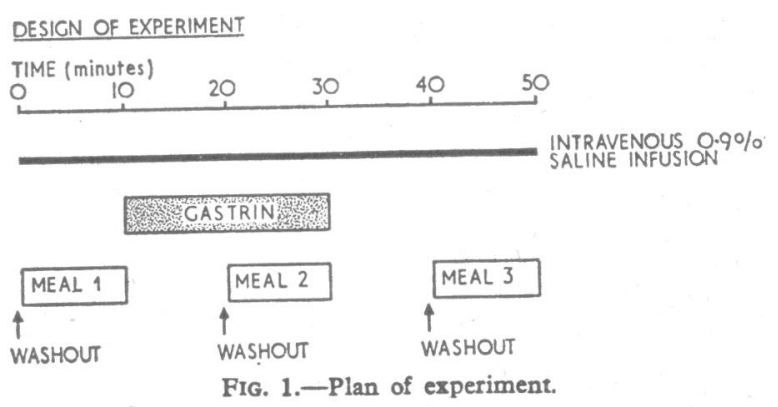

was $0.5 \mu \mathrm{g} . / \mathrm{min}$. (Fig. 2) and in subject J. H. $2 \mu \mathrm{g} . / \mathrm{min}$. (Fig. 3). In both subjects the threshold for stimulating secretion of acid in the second meal was less than that required to slow emptying $-0.125 \mu \mathrm{g}$. in N. R. and $0.5 \mu \mathrm{g}$. in J.H. (Figs. 4 and 5). With most doses the slowing of emptying had worn off in the 10 minutes between stopping the infusion of gastrin and giving the third meal. On the other hand, with the larger doses, $0.75 \mu \mathrm{g}$. in N.R. and $2 \mu \mathrm{g}$. in J.H., the secretion of acid in response to the third meal was greater than that in response to the second, though there was no injection of gastrin during the third meal.

* Department of Physiology, Guy's Hospital Medical School, London S.E.1. 


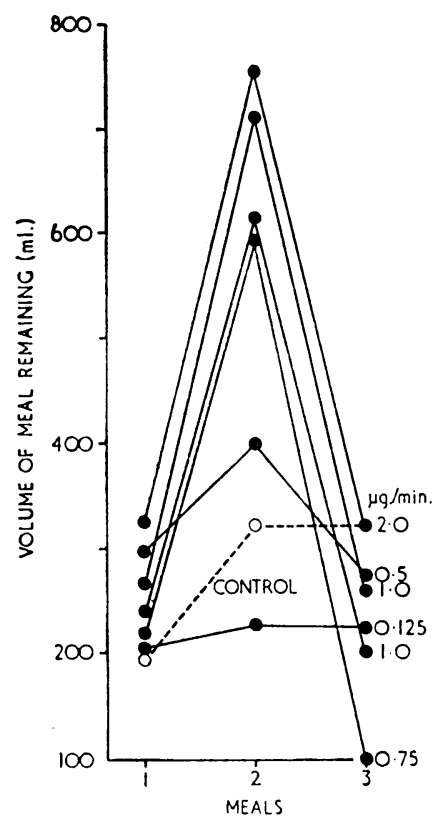

FIG. 2

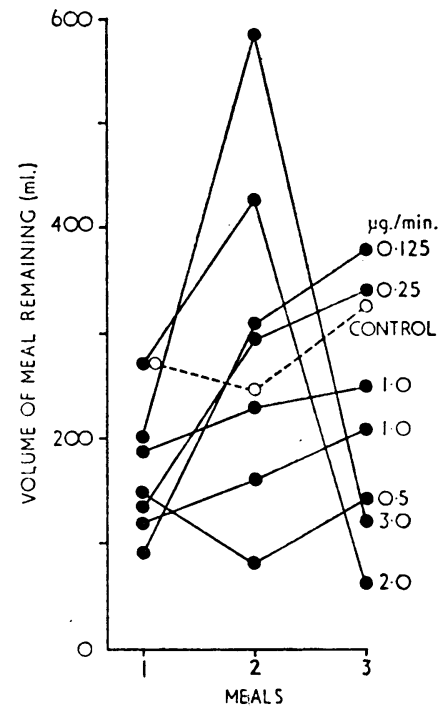

FIG. 3

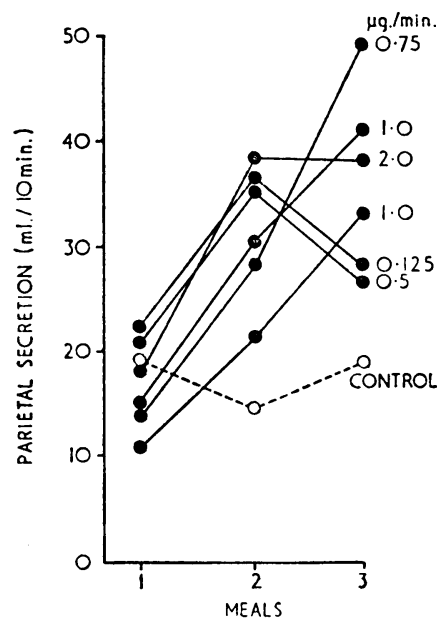

FIG. 4

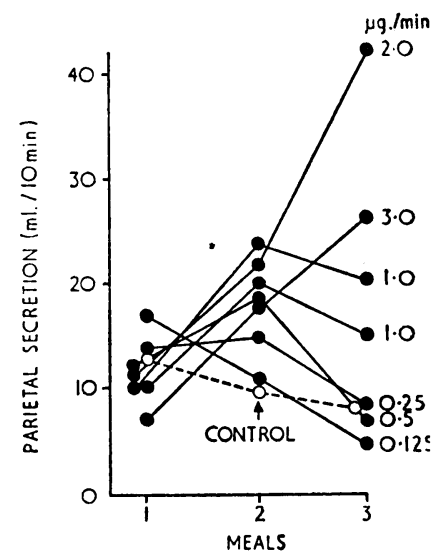

Fig. 5

FIG. 2.- Relation between dose of injected gastrin and volume of test meal remaining, N. R. Fig. 3.-Relation between dose of injected gastrin and volume of test meal remaining, J. H. FIG. 4.- Relation between dose of injected gastrin and volume of parietal secretion, N. R. FIG. 5.Relation between dose of injected gastrin and volume of parietal secretion, J. $\mathrm{H}$.

\section{Discussion}

It was believed that the hormones of the alimentary tractfor example, cholecystokinin, pancreozymin, and gastrin-had specific actions on their target organs. Originally gastrin was thought to act only on the parietal cell (Uvnäs, 1948), but more recently it has also been found to affect pepsin production and the secretion of protein by the pancreas (Emås and Grossman, 1967 ; Preshaw and Grossman, 1965). There is now evidence that gastrin also increases motility of the alimentary tract (Gregory and Tracy, 1964 ; Smith and Hogg, 1966). Because of the rapid gastric emptying seen in a patient with the ZollingerEllison syndrome, we expected infused gastrin to increase the rate of emptying. However, $0.5 \mu \mathrm{g} . / \mathrm{min}$. $(0.007 \mu \mathrm{g} . / \mathrm{kg} . / \mathrm{min}$.) in N. R. and $2 \mu \mathrm{g} . / \mathrm{min}$. $(0.03 \mu \mathrm{g} . / \mathrm{kg} . / \mathrm{min}$. $)$ in J. H. slowed the emptying of the stomach. These doses were submaximal for the secretion of acid, since the next higher dose gave a greater secretion of acid and a greater slowing of gastric emptying.

Acid in test meals slows gastric emptying (Shay and GershonCohen, 1934 ; Hunt and Pathak, 1960). However, the slowing of gastric emptying by gastrin was not caused in this way. For example, $0.75 \mu \mathrm{g}$. of gastrin per minute in N.R. increased the recovery of test meal from 200 to $600 \mathrm{ml}$. The volume of parietal component secreted during this second meal was $28 \mathrm{ml}$., and the titratable acid was $5.6 \mathrm{mEq} / 1$. of gastric contents. For the third meal the recovery of test meal was only $100 \mathrm{ml}$, yet the secretion of parietal component was $50 \mathrm{ml}$. and the titratable acidity of the gastric contents was $16 \mathrm{mEq} / 1$. The secretion of parietal component before gastrin was given was $14 \mathrm{ml}$., with a titratable acidity of the gastric contents of $3.6 \mathrm{mEq} / 1$. There was in this experiment, and in most of the others, a clear dissociation between gastric emptying and the titratable acidity of the gastric contents. Thus the slowing of emptying by gastrin was not caused by increased acidity of the gastric contents.

Gastrin and its pentapeptide analogue (I.C.I. 50.123) were found to increase the motility of the alimentary tract as indicated by changes in intraluminal pressure (Gregory and Tracy, 1964 ; Smith and Hogg, 1966). The slowing of gastric emptying by gastrin may result from a general increase in the tone of the gut. When this happens those parts of the alimentary tract with the smaller diameter are at a mechanical advantage because of the operation of the law of Laplace (Brody and Quigley, 1948). Thus contraction of the duodenum may prevent the stomach from emptying. This appears to be the mechanism by which morphine slows gastric emptying (Folley and Osler-Abbott, 1942).

The difference between the rapid evolution of the maximal slowing of emptying and the slow approach to maximal secretion is worth comment. Presumably the motor response to gastrin depends on the plasma concentration. The delay in secretory response to gastrin may be analogous to the delay in response to aldosterone, which delay is currently ascribed to the induction of an enzyme (Sharp and Leaf, 1966). This would fit in with the work of Blair (personal communication), who found that, with a single intravenous dose of gastrin, by the time the peak of acid secretion was reached the concentration of gastrin in the plasma was only $3 \%$ of the initial level.

\section{Summary}

The effect of gastrin II on gastric emptying and secretion was examined in two men. The rate of gastric emptying was slowed in proportion to the dose given. The increased rate of gastric secretion of acid long outlasted the slowing of gastric emptying.

We should like to thank Professor R. A. Gregory, who kindly supplied us with the gastrin for this experiment.

\section{REFERRNCES}

Blair, E. L. (1967). Personal communication.

Brody, D. A., and Quigley, J. P. (1948). Bull. math. Biophys., 10, 25.

Emås, S. A., and Grossman, M i. (1967). Gastroenierology, 52, 29. Folley, J J H., and Osler-Abbott, W (1942). Amer. J. dig. Dis., 9, 202. Gregory, R. A., and Tracy, H. J. (1964). Gut, 5, 103.

French, J. M., and Sircus, W. (1960). Lancet, 1, 1045. Hunt, J. N. (1954). Guy's Hosp. Rep., 103, 161. (1959). Physiol. Rev., 39, 491.

and Pathak, J. D. (1960). F. Physiol. (Lond.), 154, 254.

Lawrie, R. S., Williamson, A. W. R., and Hunt, J. N. (1962). Lancet, 1,1002 .

Preshaw, R. M., and Grossman, M. I. (1965). Gastroenterology, 48, 36 Preshaw, G. W. G., and and Leaf, A. (1966). Physiol. Rev., 46, 593 .

Sharp, G. W. G., and Leaf, A. (1966). Physiol. Rev., 46, S93.

Shay, H., and Gershon-Cohen, J. (1934). Surg. Gynec.
Smith, A. N.. and Hogg, D (1966). Lancet, 1, 403.

Uvnds, B. (1948). Acta phystol. scand., 15, 438.

Zollinger, R. M., and Ellison, B. H. (1955). Ann. Surg., 142, 709. 